\title{
Mid-Polish Trough inversion - seismic examples, main mechanisms, and its relationship to the Alpine-Carpathian collision
}

\author{
P. Krzywiec \\ Polish Geological Institute, ul. Rakowiecka 4, 00-975 Warszawa, Poland \\ (Email: krzywiec@pgi.waw.pl)
}

Received: 8 December 2000 - Accepted: 16 March 2001

\begin{abstract}
Numerous brittle deformations related to the Late Cretaceous inversion of the Mid-Polish Trough (MPT) have been identified in its various parts using seismic data. The role of Zechstein evaporitic deposits during basin evolution and inversion is also described. A model for the Pomeranian segment of the MPT has been constructed that includes significant decoupling between pre-Zechstein basement and Mesozoic sedimentary infill. In areas without significant influence of Zechstein deposits on tectonic processes, classical inversion structures have been interpreted like reverse faults and uplifted basement blocks. Thickness reductions and local angular unconformities pointing to syn-tectonic sedimentation often accompany these inversion structures. Correlation of well and seismic data allows for fairly precise dating of the inversion activity in various parts of the MPT. For the NW segment indirect observations suggest that inversion activity spanned Turonian to Campanian times, whereas in SE segment inversion could have started in Coniacian, was active in Santonian and Campanian, and reached its peak in Maastrichtian times. Inversion along the NE boundary of the MPT (Koszalin-Chojnice tectonic zone) was associated with strike-slip movements. In this area the first stage of the inversion-related uplift of axial part of the MPT can be dated as post-Turonian and pre-Maastrichtian, the second stage, related to strike-slip movements, as middle Maastrichtian. Maastrichtian is also the age of transverse strike-slip activity along Grójec fault. All these dates generally conform to the main compressive events within the Alpine-Carpathian orogenic belt, which suggests some sort of mechanical coupling between this orogenic belt and its foreland.
\end{abstract}

\section{Introduction}

Problems of basin inversion have been recently subject of intensive research due to their importance for occurrence of hydrocarbon deposits (cf. Buchanan and Buchanan, 1995;
Cooper and Williams, 1989; Coward, 1994). Numerous processes could cause basin inversion, i.e. inversion of subsidence trends. It is often related to compressional stresses transferred from zones of continental collision or active seafloor spreading. For example, Late Cretaceous-Tertiary inversion in Europe has been often attributed to Alpine collision and Atlantic spreading (Dadlez, 1980a; Dronkers and Mrozek, 1991; Erlstrom et al., 1997; Roure and Colletta, 1996; Stackenbrandt and Franzke, 1989; Schröder, 1987; Ziegler, 1989, 1990). Studies of inversion processes resulted in development of numerous models linking deep (lower crustal-mantle) ductile deformations with upper crustal brittle deformations (cf. Coward, 1994). Upper crustal inversion-related deformations include reverse and strike-slip faults that can often be detected using seismic reflection data. In this paper selected examples of inversionrelated upper crustal faults developed within pre-Zechstein basement of the Mid-Polish Trough and its sedimentary infill are described (cf. Krzywiec, 2000a, b, c, d), and their relationship to Alpine collision processes is discussed.

Two major types of inversion structures can be distinguished: fault-propagation folds (Mitra, 1990, 1993), and fault-bend folds. Numerous studies based on analogue modelling (Fig. 2) and focused on detailed characteristics of such inversion structures have been completed and provided rationale for interpretation of seismic data (Koyi et al., 1995; McClay 1989, 1995; Mitra and Islam, 1994). Within hinge zones of inversion-related folds thickness reductions of syninversion deposits accompanied by localised progradational pattern are often observed and point to syn-depositional tectonic activity (Cartwright, 1989). Such features are similar to that observed e.g. within frontal parts of orogenic belts (Hardy et al., 1996; Krzywiec, 1997, 2001). Strike-slip movements and development of flower structures also often accompany inversion processes, especially when compressional stresses responsible for basin inversion are obliquely oriented to the extensional fault zones (Harding, 1985; Lihou and Allen, 1996; Woodcock and Schubert, 1994). 


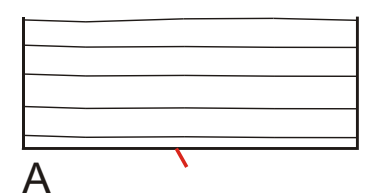

$2 \mathrm{CM}$
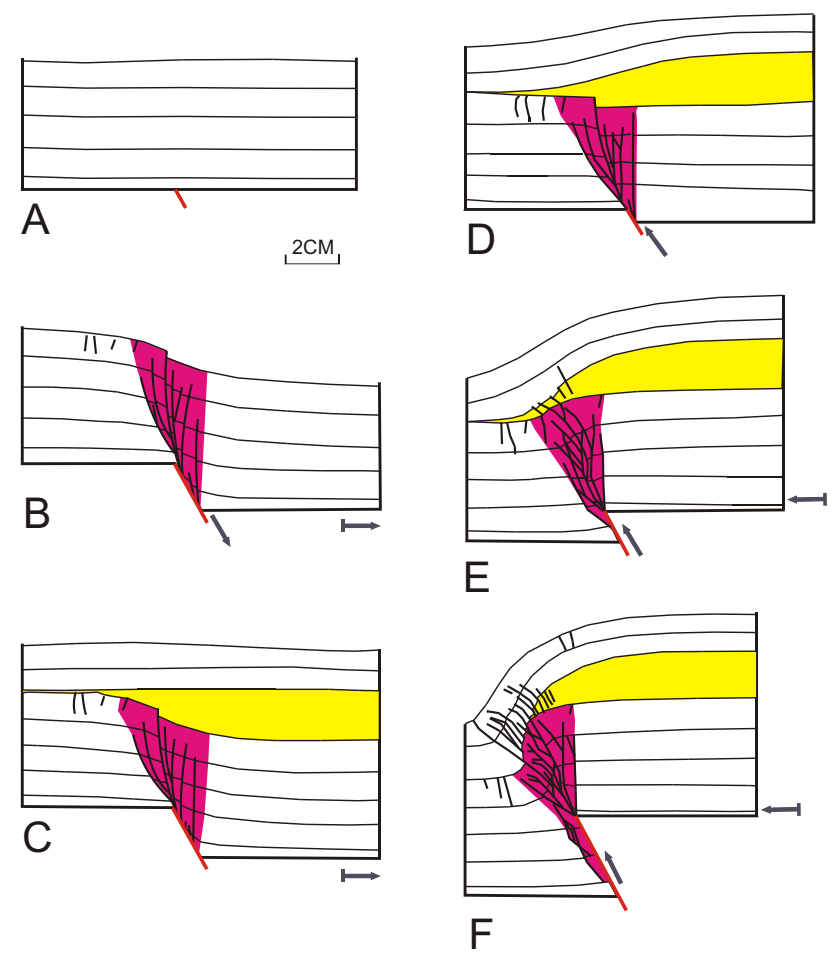

Fig. 1. Inversion of normal fault-results of analogue modelling (from Mitra and Islam, 1994, slightly modified). Stages (a)-(c): extension, stages (d)-(f): inversion. Yellow - syn-extensional deposits.

\section{Geological setting}

Mid-Polish Trough (MPT) belonged to the system of epicontinental depositional basins of western and central Europe and formed SE axial part of the Danish-Polish Basin (Michelsen, 1997, Ziegler, 1990; van Wees et al., 2000). It developed from Permian to Cretaceous times and was filled with several kilometres of sediments, mainly siliciclastics and carbonates. (e.g. Dadlez, 1997; Pożaryski and Brochwicz-Lewiński, 1978, 1979). Important part of the sedimentary infill is formed by thick Zechstein evaporites (Wagner, 1998). MPT was located along the NW-SE trending Tornquist-Teisseyre Zone (Fig. 1; Dadlez, 1997; Karnkowski, 1999). It stretched from the Baltic Sea towards SE, and starting from Jurassic times it also included area of the presentday E Carpathian Foredeep basin (cf. Dadlez, Marek and Pokorski, 1998; Hakenberg and Świdrowska, 1997, 1998a; Kutek, 1994; Pożaryski and Żytko, 1981). During basin evolution numerous salt structures were formed (Dadlez and Marek, 1974; Pożaryski, 1977; Sokołowski, 1966, 1972).

One of the major problems concerning evolution of the MPT is apparent lack of extensional deformations responsible for several pulses of tectonic subsidence inferred from tectonic modelling (Dadlez et al., 1995; van Wees et al., 2000). These deformations (normal faults) could have been reactivated during basin inversion. Recently, several authors pointed directly to this problem, emphasising its impor- tance for understanding of this sedimentary basin evolution (Dadlez, 1997; Stephenson and Narkiewicz, 1999).

MPT was inverted in Late Cretaceous-Palaeocene times, at which time its axial part was strongly eroded (Pożaryski and Brochwicz-Lewiński, 1979; Ziegler, 1990). In its SE part (Holy Cross Mnts.; Fig. 2) Palaeozoic basement was exposed as a result of this inversion. Numerous publications related to the MPT inversion have been presented so far (e.g. Dadlez and Marek, 1969; Dadlez, 1997; Kutek, 1994; Pożaryski, 1977; Pożaryski and Brochwicz-Lewiński, 1979). Most of these papers however mainly dealt with deep crustal processes responsible for basin inversion (Dadlez, 1980a; Dadlez et al., 1994, 1995). Vertical uplift of the axial part of the basin was attributed to phase changes and transition of eclogite into gabbro, and related crustal isostatic movements (Dadlez, 1980a; Znosko, 1979); the role of regional compressional stresses in this process was also discussed.

Development of brittle inversion structures received much less attention due to lack of reliable data. The very few outcrops suitable for studying the inversion processes are all found in SE Poland: Holy Cross Mts., Radom-Kraśnik Elevation and Lublin Trough (e.g. Jaroszewski, 1972; Lamarche et al., 1998; Pożaryski, 1948, Stupnicka, 1971, 1972). The locations of particular fault zones active during extension (Permian-Early Cretaceous) were postulated using mostly indirect information such as regional thickness and facies changes known from regional analysis of well data (Dadlez, 1980b; Hakenberg and Świdrowska, 1997, 1998a, 1998b; Świdrowska and Hakenberg, 1999, 2000; Kutek and Glazek, 1972). Only selected authors (e.g. Pożaryski, 1948, 1957, 1977, 1997; Pożaryski and Brochwicz-Lewiński, 1979) suggested reverse character of the inferred basement faults, but without any detailed analysis of their relationship to inversion processes.

Very strong attenuation of seismic energy by Zechstein evaporites and the related low quality of seismic data from deeper (i.e. pre-Zechstein) complexes made construction of structural model for MPT's basement very difficult. Few publications only contained direct interpretation of preZechstein basement structure (e.g. Antonowicz, Iwanowska and Rendak, 1994). More typically, published papers contained interpreted seismic profiles with tectonic deformations that were restricted to the Mesozoic infill and drawn as wide vertical deformation zones (Dadlez, 1980a; Dadlez and Marek, 1974).

Another problem related to evolution of the MPT is the relationship of basement tectonic processes to salt structure development. Numerous authors have addressed this issue (Dadlez and Marek, 1974; Pożaryski, 1977; Sokołowski, 1966, 1972), but only a general link between inferred basement tectonic activity and salt movements was suggested, and no detailed genetic model of such linked processes has been proposed so far. 


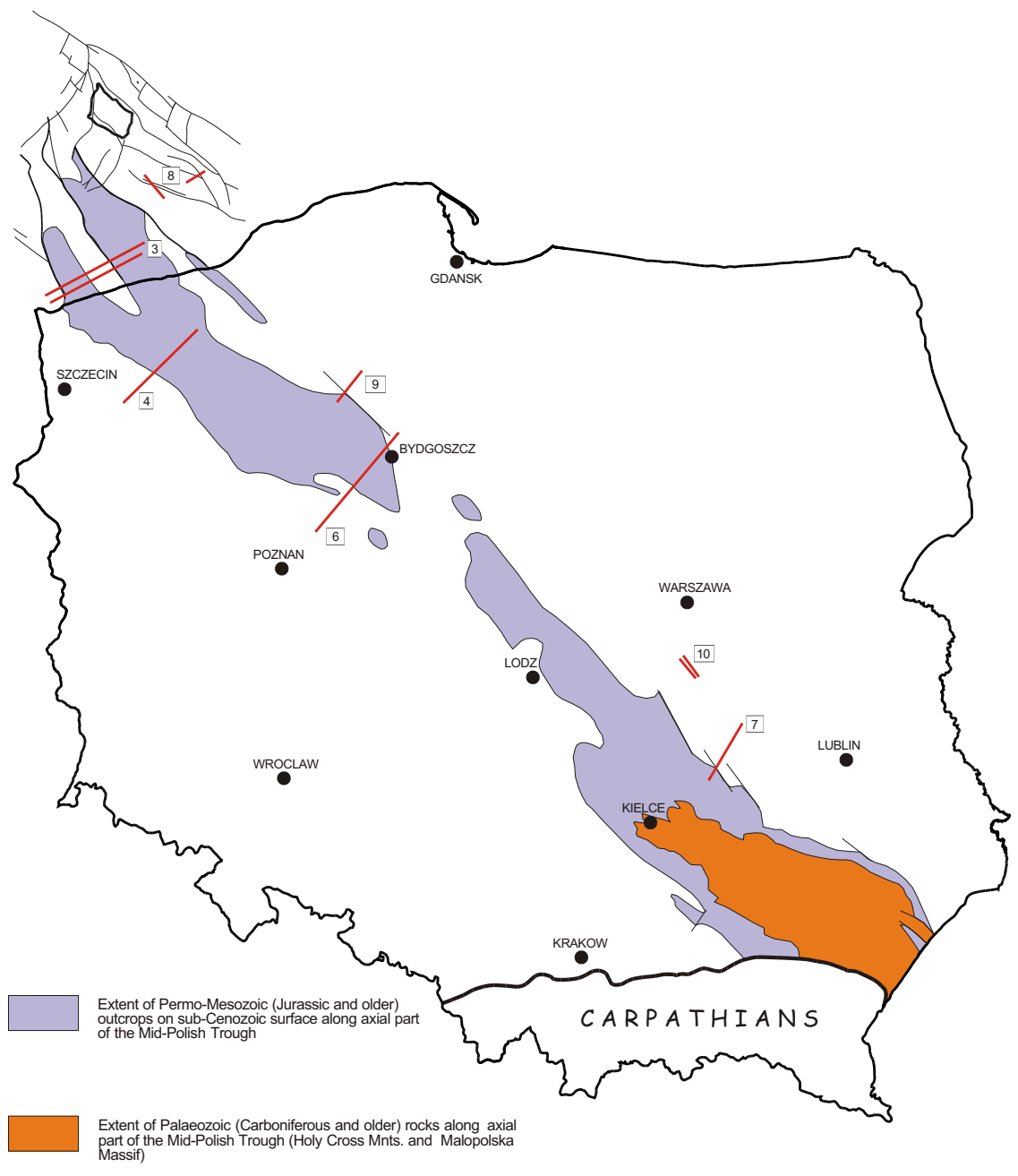

Fig. 2. Location map of interpreted seismic profiles at the background of geological sketch of the Mid-Polish Trough. Tectonics of SW Baltic Sea after Kramarska, Krzywiec and Dadlez (1999) and Schlüter et al. (1997), simplified. Numbers indicate numbers of figures with interpreted seismic profiles.

\section{Mid-Polish Trough inversion - main structures and processes}

Two major groups of inversion deformations from the MPT have been recognised using seismic data: 1) rotated and uplifted basement blocks bordered by reverse faults and accompanied by fault-propagation folds, and 2) basement pop-up structures and flower structures related to strike-slip movements.

\subsection{Basement blocks bounded by reverse faults}

Basement blocks bounded by reverse faults form the most typical inversion structures (Hayward and Graham, 1989; Williams, Powell and Cooper, 1989). Such features have been recently, directly or indirectly, recognised in various parts of the inverted MPT.

\subsubsection{Offshore part of the MPT - S Baltic Sea}

In the S Baltic Sea, the NW-SE trending Kamień Pomorski and Trzebiatów faults (Dadlez and Młynarski, 1967; Dadlez et al., 1998; Kramarska, Krzywiec and Dadlez, 1999;
Pożaryski and Witkowski, 1990; Pożaryski, BrochwiczLewiński and Jaskowiak-Schoeneich, 1978) form major inversion-related structures (Fig. 3). They form a typical extensional fault system inverted in a compressional tectonic regime (cf. Schlüter et al., 1997). Major reverse faults presumed within the pre-Zechstein basement are accompanied by asymmetric fault-propagation folds developed within the Mesozoic infill. Due to strong uplift of inversion anticlines, related deep erosion and lack of preserved syn-inversion deposits it is not possible to determine precisely the timing of inversion for this part of the MPT.

In the NW part of the MPT (off-shore area of present-day Baltic Sea) Zechstein evaporites are either absent or of small thickness (Wagner, 1998). Therefore, their role during basin evolution and inversion as decoupling level (see below) was negligible.

Towards the south, close to the Polish coast, reverse faults related to basin inversion become most probably restricted to pre-Zechstein basement, and overlying Mesozoic sedimentary infill is deformed mostly by fault-propagation folds. 

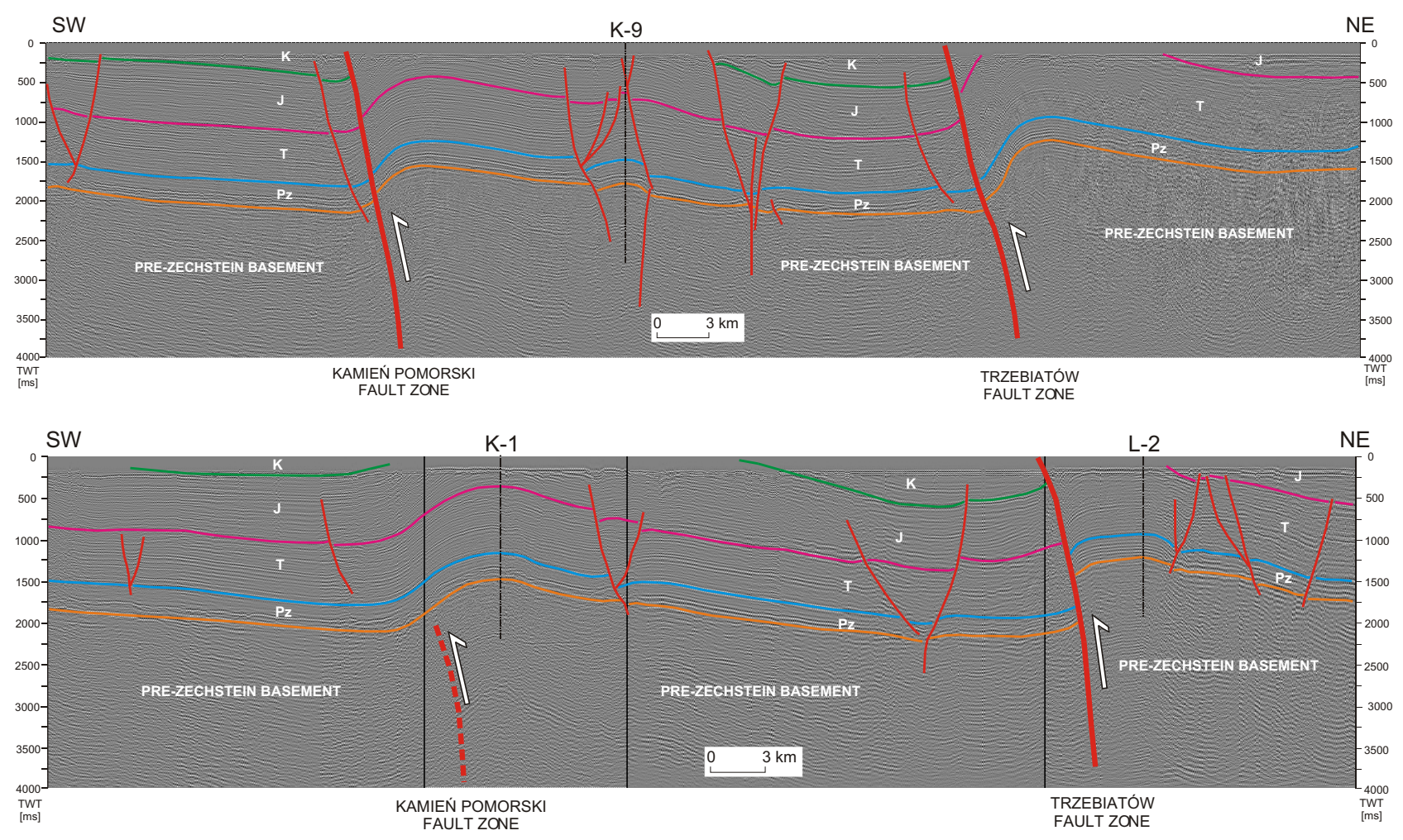

Fig. 3. Seismic profiles from the western part of the S Baltic Sea (NW Mid-Polish Trough) showing major inversion structures. Location see Fig. 2. Pz - Zechstein, T - Triassic, J - Jurassic, K - Cretaceous.

\subsubsection{Onshore part of the MPT - Pomeranian and central segments}

Similar basement-involved inversion structures can be found in onshore part of the MPT. In its Pomeranian segment uplifted basement blocks possibly bordered by reverse faults can be inferred from available seismic profiles (Fig. 4). Axial part of the MPT is strongly uplifted and forms so-called Mid-Polish Swell (MPS). The area of present-day uplift is also characterised by increased thickness of Zechstein and Triassic deposits. Jurassic and Cretaceous series, due to uplift and erosion, have been nearly entirely removed hence it is difficult to estimate their initial thickness. However, divergent pattern of Jurassic reflectors on both sides of uplifted MPS suggests that also Jurassic series had their depocenter in vicinity of present-day uplifted MPS. All these features are in agreement with earlier conclusions that maximum subsidence of the MPT, at least in its Pomeranian segment, was located in its axial part (cf. Pożaryski, 1957; Dadlez and Dembowska, 1959; Dadlez, Marek and Pokorski, 1998). It must be however stressed that Mesozoic sedimentary infill of the axial MPT is not cut by any important faults possibly responsible for tectonic subsidence. This could be explained by basin-scale mechanical decoupling between preZechstein (precisely between pre-Stassfurt salt) basement and Mesozoic sedimentary infill. Recently published results of analogue modelling of active faulting beneath salt layer (Withjack and Calloway, 2000) clearly show that presence of thick salt layer above the basement deformed in brittle fashion strongly modifies modes of deformation of post-salt overburden. Mechanical decoupling between two brittle layers (pre- and post-salt successions) leads to generally more gentle depositional pattern of the sedimentary infill-gradual thickness changes, divergent seismic pattern, gentle overstepping of younger sediments, etc (comp. Withjack and Calloway, 2000 and their Fig. 14). This is particularly true for a relatively thick viscous salt layer - well-documented feature of the MPT, as within axial part of this sedimentary basins up to $1,5 \mathrm{~km}$ of Zechstein evaporites with total thickness of salt in order of $1 \mathrm{~km}$ have been deposited (Wagner, 1998). During such "decoupled" extensional evolution major normal faulting is primarily restricted to the basement, and only secondary normal faults and associated deformations such as extensional forced folds or salt structures develop within the sedimentary infill (Withjack et al., 1990; Koyi et al., 1993; Koyi and Petersen, 1993). Thickness changes are gentle and not directly related to normal fault zones. During basin inversion basement normal faults could be reactivated as reverse faults and responsible for uplift of basement blocks. However, their activity would most probably also be generally restricted to the basement, and only secondary deformations related to inversion activity would develop within the sedimentary infill.

In SW part of the analysed seismic profile local compressional structures possibly genetically related to inversion processes have been detected (Fig. 4 and 5). These defor- 


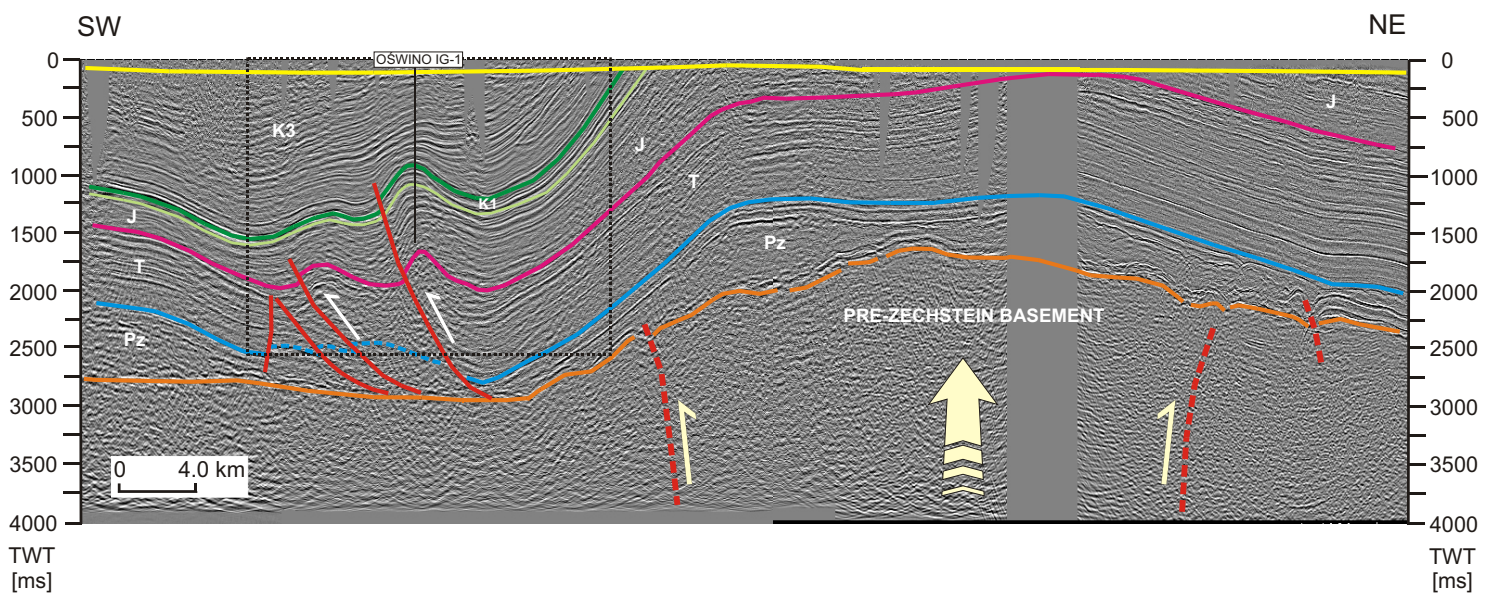

Fig. 4. Seismic profile from axial part of the Mid-Polish Trough (Pomeranian segment) showing presumed major inversion structure: basement block uplifted along reverse faults; Pz - Zechstein, T - Triassic, J - Jurassic, K1 - Lower Cretaceous, K2 - Upper Cretaceous. Note thickness increase of Triassic and Jurassic deposits towards the inverted axial part of the Mid-Polish Trough and asymmetrical, divergent seismic pattern (lower part of Upper Cretaceous section) above compressional structures located SW from the axial part of the profile. Due to low quality of seismic data from beneath of the Zechstein interval major reverse faults drawn within the basement should be regarded as hypothetical fault zones responsible for basin inversion. Location - see Fig. 2. Black square - enlarged portion of seismic profile shown on Fig. 5, large arrow - general vertical movement within the axial part of the MPT.

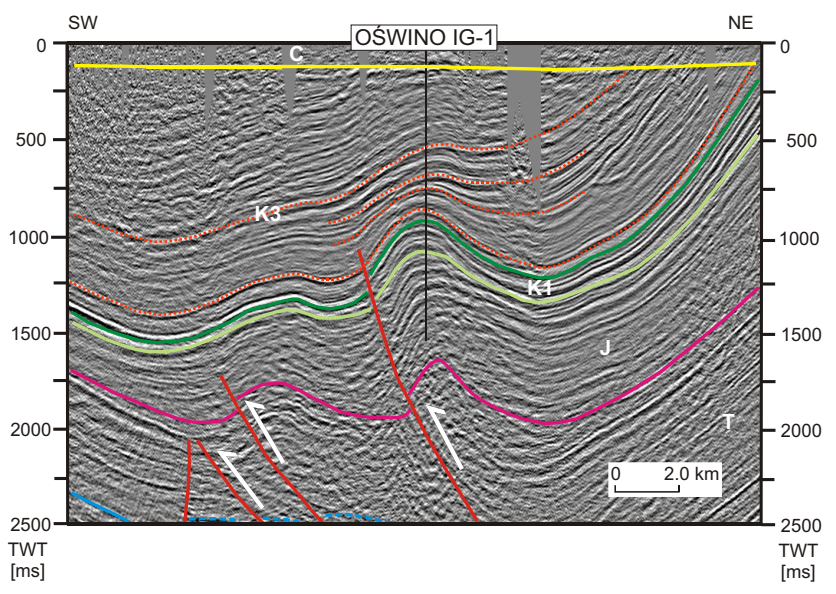

Fig. 5. Enlarged part of seismic profile from Fig. 4 with secondary syn-sedimentary compressional structures detached within the Zechstein evaporites and developed within the Mesozoic deposits due to inversion processes. Red dotted line - syn-compressional deposites (Turonian to Campanian) developed during growth of thrust deformations. C - Cenozoic, other symbols - see Fig. 4.

mations have been interpreted by other authors as pure salt structures (cf. Jaskowiak-Schoeneich, 1979). In this paper their origin has been attributed to compressional stresses and they are interpreted as imbricated fan of blind reverse faults (cf. Dunne and Ferill, 1988; Mitra, 1986) and related faultpropagation folds. Significant thickness reductions within the hinge zone of fault-related folds and local angular unconformities (Fig. 5) point to syn-depositional tectonic activity. Uplift of fold hinge zone and related local reduction of accommodation space have caused thickness reductions of syn- tectonic deposits. Progressive rotation of backlimb accompanied by sediment progradation from uplifted source area leads in turn to the formation of local angular unconformities. All these features are very common in frontal parts of foreland fold-and-thrust orogenic belts, where frontal thrusts are buried beneath water and older deposits of foredeep basins become involved in thrusting movements and they are covered by younger foredeep deposits (comp. Hardy et al., 1996; Krzywiec, 1997, 2001; Burbank and Verges, 1994). Similar processes can also be observed above basement blocks reactivated and uplifted during basin inversion (Cartwright, 1989).

Mechanism of formation of these secondary compressional structures was probably similar to one which was responsible for formation of Perdido, Mississippi Fan and Mexican Ridges fold belts of the Gulf of Mexico (Rowan, Jackson and Trudgill, 1999; Trudgill et al., 1999). In this area various compressional structures developed due to morphological gradient related to continental slope, and increased pressure of overburden rocks related to up-slope deposition. In case of inversion-related structures of the MPT, morphological gradient and increased pressure of overburden rocks could have been created by uplift of axial part of the basin, and accompanied by development of detachment surface within ductile Zechstein deposits. Fault planes reactivated during Late Cretaceous inversion might have originally developed as secondary normal faults during decoupled extensional stage. Local increase of Upper Triassic deposits with hinge zone of these structures suggests Late Triassic extension. In case of analysed Pomeranian segment of the MPT, significant thickness reductions within the hinge zone of fault-related fold (Oświno IG-1 well and its surroundings - see Fig. 5) are observed mainly for Turonian to Campa- 


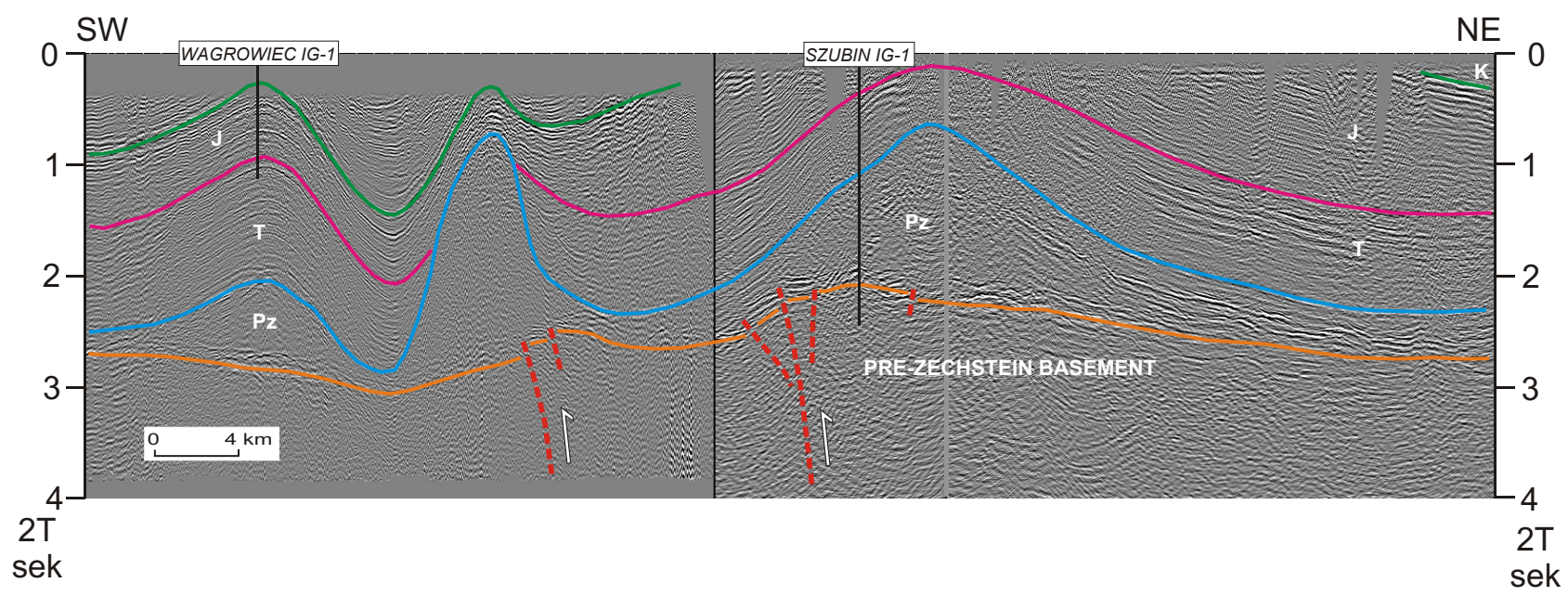

Fig. 6. Seismic profile from central (axial) part of the Mid-Polish Trough (Waggrowiec-Szubin area) showing basement inversion structure and genetically-related Szubin salt pillow. Due to low quality of seismic data from beneath the Zechstein interval exact location and reverse character of basement faults should be regarded as hypothetical. Compare basement geometry related to inversion to stages $\mathrm{E}$ and $\mathrm{F}$ from Fig. 1. Location - see Fig. 2. Pz - Zechstein, T - Triassic, J - Jurassic, K - Cretaceous.

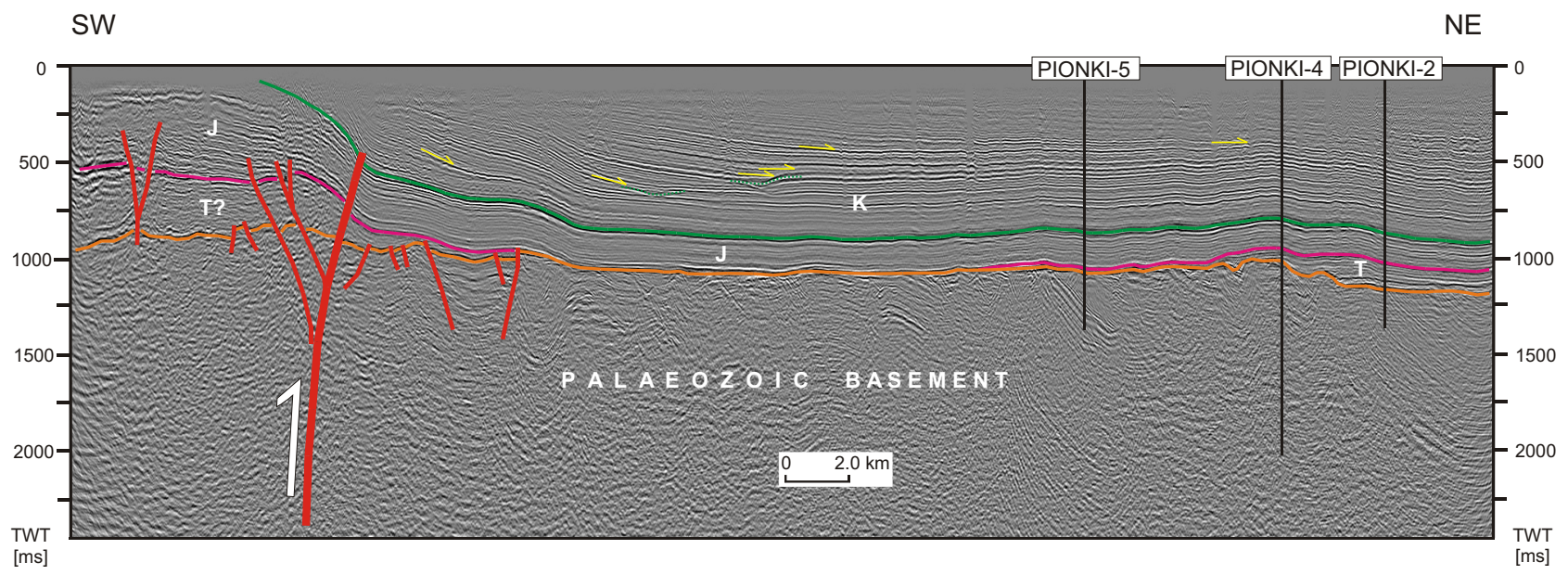

Fig. 7. Seismic profiles from Radom-Kraśnik Elevation (SE segment of the Mid-Polish Trough) showing Late Cretaceous inversion-related structures. Note thickness changes, local angular unconformities (yellow arrows) and incised valleys (green dotted lines) within the Upper Cretaceous deposits that point towards their relationship with the inversion processes. Location - see Fig. 2. T - Triassic, J - Jurassic, K Cretaceous.

nian deposits, and they indirectly date uplift and inversion of this segment of the MPT. Presumed MPT uplift of such age is also documented by slight thickness decrease of presumably syn-tectonic (= syn-uplift; see Fig. 4 and 5) Turonian to Campanian deposits towards the NE, i.e. towards uplifted MPT's axial part.

Uplifted basement blocks along the reverse faults can also be presumed in central part of the MPT, e.g in vicinity of Szubin IG-1 well (Fig. 6). They are accompanied by footwall shortcut reverse faults (cf. McClay and Buchanan, 1992), salt structures (pillows) and fault-propagation folds developed within the Mesozoic deposits. Significant thickness of Zechstein deposits (up to $1,5 \mathrm{~km}$ ) known from restored geological maps for this area (Wagner, 1998) might be explained by supposed basement normal fault. During inversion stage this fault could have been reactivated as a reverse fault, while supposedly evaporitic deposits of locally increased thickness were transformed into Szubin salt pillow present above master reverse fault (see Krzywiec, 2000a for more detailed discussion). Thickness reductions of Triassic deposits above Szubin salt pillow document earlier stages of its development, during extensional stage of MPT evolution (cf. Koyi, Jenyon and Petersen, 1993).

\subsubsection{SE part of the MPT - Radom-Kraśnik Elevation}

Inversion structures were also identified within the RadomKraśnik Elevation. In this area, due to relatively larger number of outcrops, presence of fault-related Mesozoic folds 
has been already postulated on the basis of field studies (Pożaryski, 1948, 1997; Jaroszewski, 1972). These faults belong to so-called Nowe Miasto-Ostrowiec ŚwiętokrzyskiZawichost (Pożaryski, 1948, 1997) or Nowe Miasto-Iłża (Hakenberg and Świdrowska, 1997, 1998a; Świdrowska and Hakenberg, 1997, 1998a) fault zone. This fault zone was active during Permian-Mesozoic evolution of this segment of the MPT. Recently acquired seismic profiles confirmed that they form typical system of inverted normal faults, with their SW parts characterised by significantly increased thickness of Mesozoic deposits related to their extensional activity (Fig. 7). Inversion structures are accompanied by thickness reductions and progradational patterns within the Upper Cretaceous deposits. Such features are typical for syndepositional tectonic activity. Thickness reduction above uplifted basement blocks, localised erosion and relatively short distance of sediment supply resulted in thickness reductions and progradational pattern in close vicinity of master reverse faults - typical for hinge zone of fault-related fold. Shortterm inversion-related tectonic activity could have also trigger local relative sea-level changes, result in local increased erosion and in development of incised valleys-features well visible on seismic profiles (Fig. 7). Correlation of seismic data with deep wells like Pionki-1, Pionki-4, Pionki-2, Plusy IG-1, Ciepielów IG-1 (Niemczycka, 1974) or Bạkowa IG-1 (Niemczycka, 1975) showed that inversion processes in this segment of the MPT could have possibly started in Coniacian, were active in Santonian and Campanian, and reached their peak in Maastrichtian.

Described structures present along NE boundary of the MPT could also be found further towards the SE, towards present-day Carpathian front. They were active in Jurassic times as extensional features (Izotova and Popadyuk, 1996; Kutek, 1994; Pożaryski and Żytko, 1981) and possibly became inverted in Late Cretaceous what led to uplift of Małopolska Block. Because of strong post-inversion erosion only remnants of Mesozoic rocks are preserved within the present-day E Carpathian Foredeep basin and its NE margin (Oszczypko et al., 1989). Discussed basement faults were again reactivated as normal faults during Miocene flexure of the Carpathian foreland plate, and slightly inverted in Sarmatian due to compressional stresses transferred from the Carpathian collision zone, partly in strike-slip regime (Krzywiec, 1997, 1999, 2001).

\subsection{Strike-slip structures}

Another group of inversion-related structures from the MPT consists of deformations related to strike-slip movements. Strike-slip inversion-related tectonic activity has already been suggested in numerous publications (Dadlez, 1994; Herbich, 1984; Pożaryski, 1977).

\subsubsection{Offshore part of the MPT - S Baltic Sea}

Wide zone of strike-slip deformations related to inversion of the MPT has been recently identified on high-resolution seis-
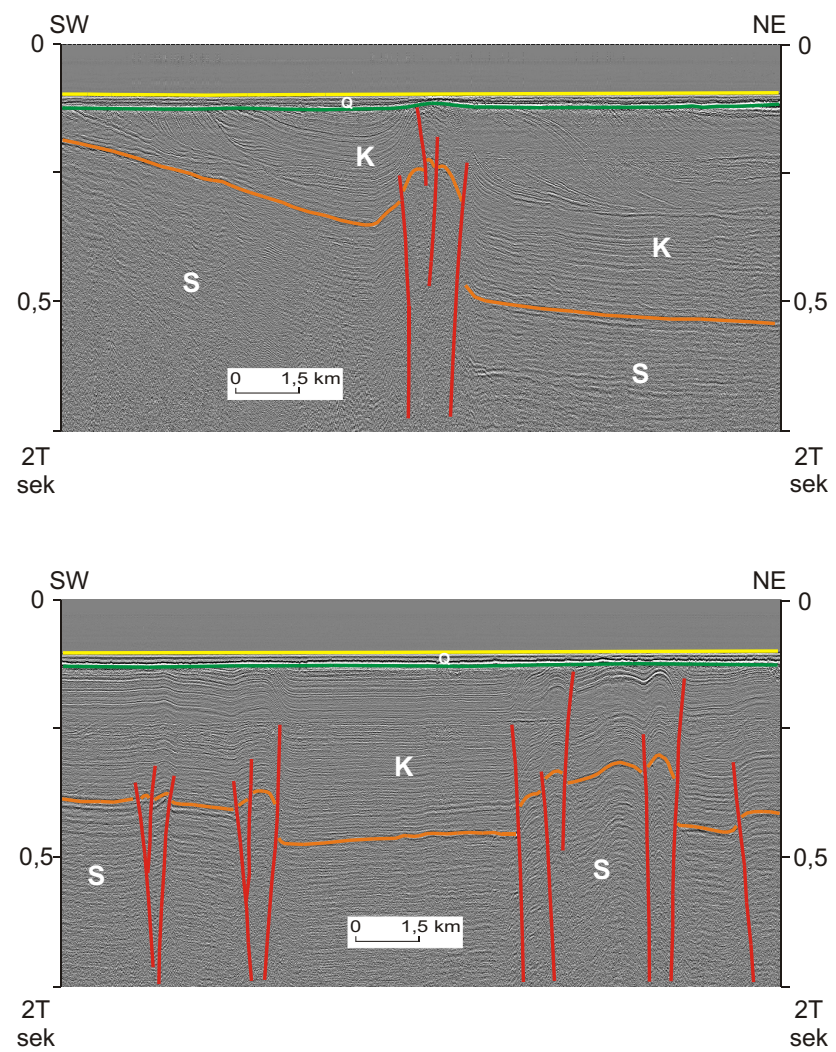

Fig. 8. High-resolution seismic profiles from central part of the S Baltic Sea (Bornholm-Darłowo fault zone) showing reverse faults and uplifted basement blocks related to strike-slip faulting and inversion (from Kramarska, Krzywiec and Dadlez, 1999). Base of Quaternary after Kramarska (op. cit.), Cretaceous / Silurian boundary uncertain due to lack of wells. Note progradational pattern and syn-inversion depositional sequences of the Upper Cretaceous deposits (upper profile). Location - see Fig. 2. S - Silurian, K Cretaceous, Q - Quaternary.

mic profiles acquired in S Baltic Sea, in area between Bornholm island and the Polish coast (Kramarska, Krzywiec and Dadlez, 1999). This area is located east from Koszalin fault zone - tectonic zone regarded as NE boundary of the MPT sensu stricto. However, parts of wider Mesozoic DanishPolish basin located e.g. in area between Bornholm island and onshore Poland have also been influenced by tectonic movements that led to the MPT inversion.

In area between Bornholm island and onshore Poland (socalled Bornholm-Darłowo fault zone, cf. Kramarska, Krzywiec and Dadlez, 1999) Maastrichtian deposits crop out on the sub-Quaternary surface (Pożaryski and Witkowski, 1990). Cretaceous deposits rest mostly on Silurian basement. Only in closer vicinity of the coastline, in relatively narrow belt, Permian, Triassic and Jurassic deposits are also present below the Cretaceous cover (Kramarska, Krzywiec and Dadlez, 1999).

Bornholm-Darłowo fault zone forms direct continuation of tectonic zone known from SW surroundings of Bornholm island (Deeks and Thomas, 1995; Vejbaek et al., 1994). Iden- 


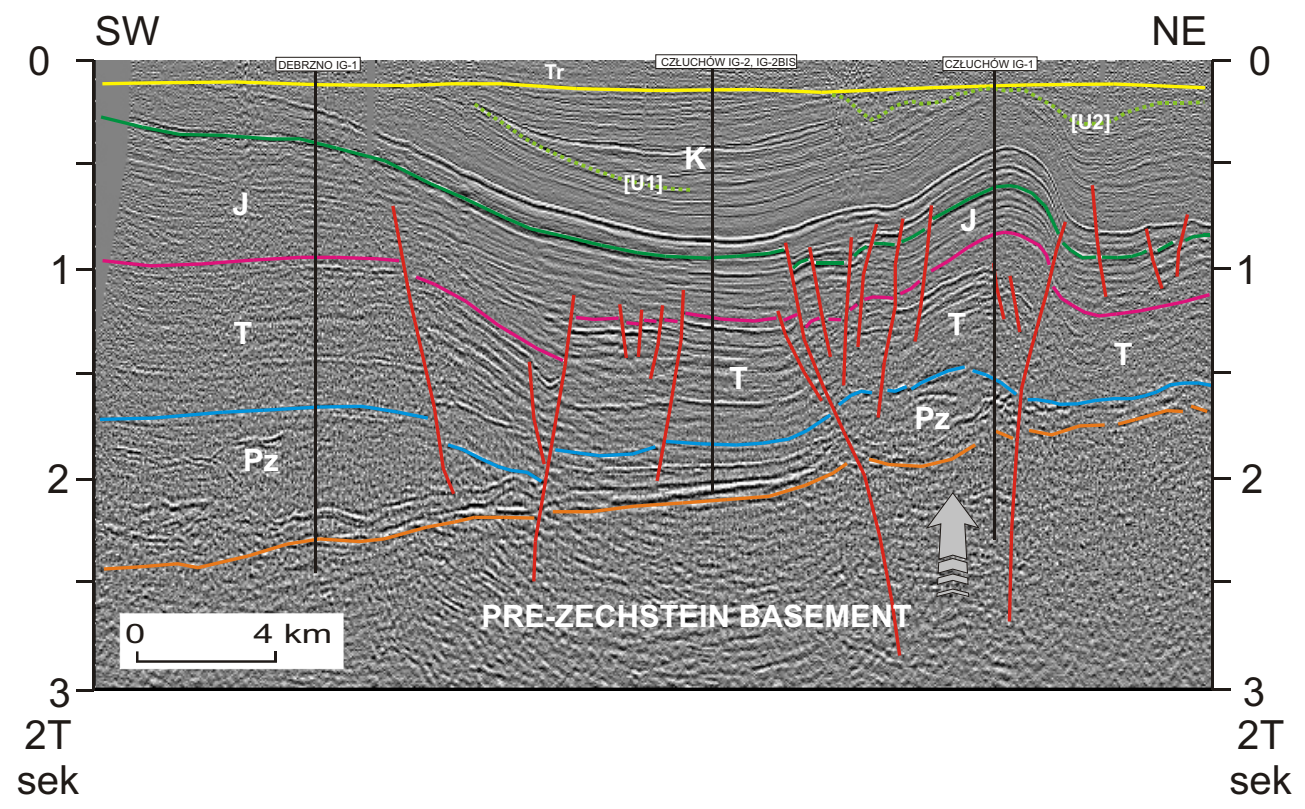

Fig. 9. Seismic profiles crossing Koszalin-Chojnice tectonic zone (Debrzno-Człuchów area) showing transpressional inversion structure. Location - see Fig. 2., Pz - Zechstein, T - Triassic, J - Jurassic, K1 - Lower Cretaceous, K2 - Upper Cretaceous, Tr - Tertiary. U1 and U2 (green dotted lines): intra-Cretaceous unconformities related to two stages of the Mid-Polish Trough inversion (see text for further explanation).

tified structures include several uplifted basement blocks and narrow basement pop-up structures - positive flower structures (Fig. 8). Bounding fault could be correlated for relatively long distances, in order of several tens of kilometres (cf. Kramarska, Krzywiec and Dadlez, 1999). Towards the Southeast, i.e. towards the Polish coastline, all these faults become broader and have smaller structural relief. All the identified features point to Late Cretaceous strike-slip movements within this part of the MPT. Such a tectonic activity resulted from relatively rigid behaviour of uplifted Bornholm island and related channelling of tectonic movements around this uplifted basement block (Deeks and Thomas, 1995). Uplift of particular blocks led to their erosion and formation of syn-tectonic deposits. Numerous examples of such syn-inversion deposition have been reported from immediate vicinity of Bornholm island (Deeks and Thomas, 1995). Seismic data located farther to the Southeast prove that also smaller uplifted blocks most probably shed sediments during inversion and related erosion. This can be observed as prominent sediment progradation (Fig. 8). Several seismic sequences observed in this area formed as a response to relative sea-level changes controlled either by tectonic movements related to basin inversion or by eustatic sea level changes, or both.

\subsubsection{NE border of the MPT - Koszalin-Chojnice zone}

NW-SE trending inversion structures can also be observed along NE border of the MPT, along so-called KoszalinChojnice zone (Dadlez and Marek, 1969; Dadlez et al., 1998; Pożaryski and Brochwicz-Lewiński, 1979). In this relatively narrow zone strong localised subsidence took place mainly in Triassic and Jurassic and was possibly related to local strike-slip movements, transtension and formation of small pull-apart basins (Pietsch and Krzywiec, 1996; Strzetelski et al., 1995). During Late Cretaceous this zone was reactivated, most probably in transpressional regime. This led to formation of positive flower structures within the Mesozoic deposits. One example of such a structure comes from Debrzno-Człuchów area (Fig. 9). Upper Cretaceous deposits in this area consist of Cenomanian and TuronianMaastrichtian series (Szyperko-Śliwczyńska, 1977). Cenomanian deposits have fairly uniform thickness in order of several tens of meters, Turonian-Maastrichtian deposits are mostly non-divided and have thickness up to several hundreds of meters. Only in well Człuchów IG-1 TuronianMaastrichtian boundary was defined, but its location was described as uncertain (Dembowska, 1977). Earlier works emphasised existence of intra-Cretaceous unconformities within the Koszalin-Chojnice zone (Jaskowiak-Schoeneich, 1976) that could have been caused by local tectonic movements. Interpretation of seismic data showed that inversion in this area took place in at least two stages. During first episode axial part of the MPT was uplifted and younger strata deposited in flanking trough onlapped uplifted older deposits. This has resulted in formation of angular unconformity marked on Fig. 9 as [U1]. During second stage of inversion-related tectonic activity positive flower structure of Człuchów area was formed. Its topmost part was eroded and unconformably covered by younger deposits, what is evidenced by erosional unconformity marked as [U2] on Fig. 9. Correlation of seismic data with Człuchów IG-2, Człuchów IG-2BIS and 

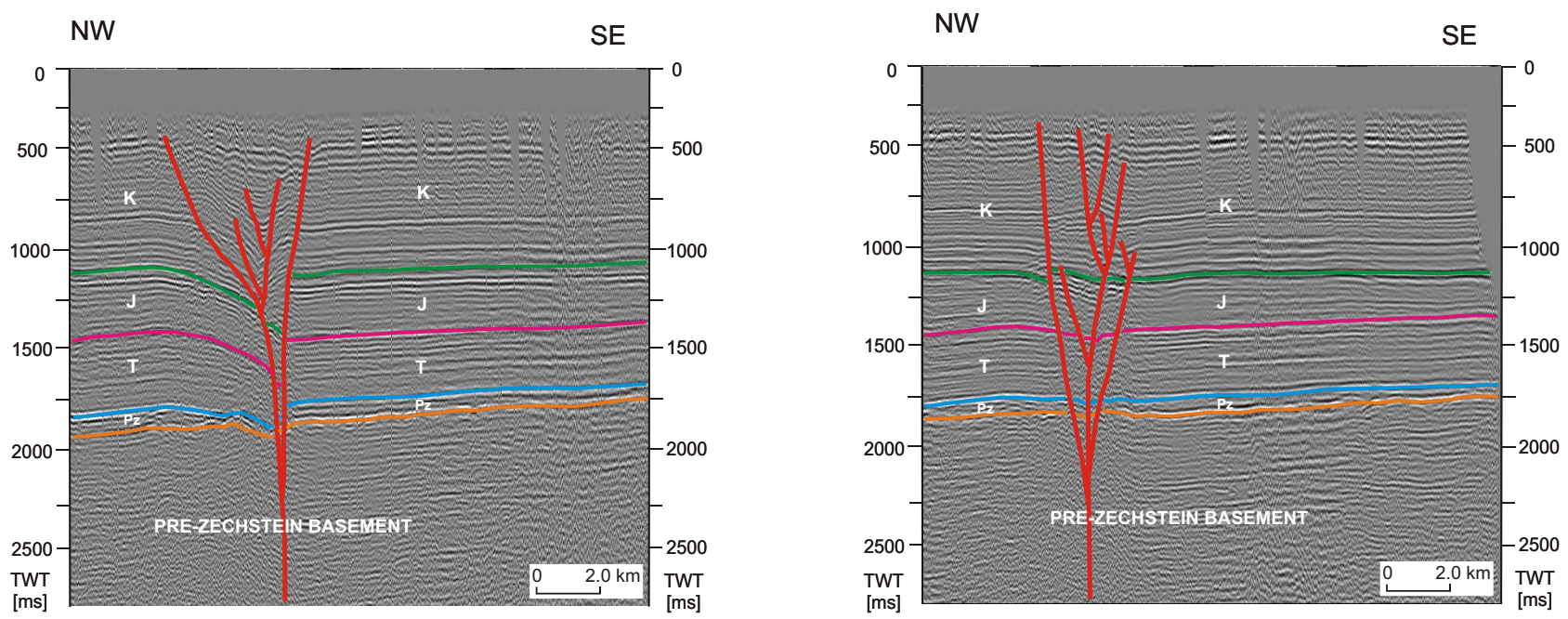

Fig. 10. Two seismic examples of strike-slip NE-SW - oriented Grójec fault (central part of the Mid-Polish Trough). Location - see Fig. 2. $\mathrm{T}$ - Triassic, J - Jurassic, K - Cretaceous. Note various modes of deformation - from transpression (positive flower structure - right profile) to transtension (negative flower structure - left profile).

Człuchów IG-1 wells suggests that possibly first phase of inversion could be dated as post-Turonian, and second one as mid-Maastrichtian. It must be stressed however, that because of stratigraphic uncertainties mentioned above these age estimates for MPT inversion should be regarded as approximate. Due to high quality of seismic data very accurate dating of particular tectonic episodes related to Late Cretaceous MPT inversion could be provided, and future work should concentrate on verification of well stratigraphy.

\subsubsection{Transversal strike-slip zone - Grójec fault}

NW-SE strike-slip movements, active during MPT inversion, were accompanied by development of NE-SW fault zones of similar character (cf. Dadlez, 1994, 1997). Transversal fault zones were reported from other extensional domains, also their reactivation during basin inversion as strike-slip fault zones was described (Cartwright, 1987). Within the MPT Grójec fault zone formed most prominent NE-SW trending fault zone of strike-slip character (Dadlez, 1994, 1997; Żelichowski, 1983). This fault zone has been active already during Palaeozoic (Żelichowski, 1983), and reactivated during MPT inversion. Seismic profiles clearly document its Late Cretaceous strike-slip character (Fig. 10). Correlation with deep wells shows that its activity related to basin inversion took place in Maastrichtian, however detailed verification of archive well stratigraphy would be necessary in order to precisely date strike-slip activity along Grójec fault zone. This zone is characterised by various types of deformations along its strike (both positive and negative flower structures - see Fig. 10). Such a deformation pattern is typical for strike- slip movements with fault planes active simultaneously both in normal and reverse mode (Biddle and ChristieBlick, 1985; Christie-Blick and Biddle, 1985; Woodcock and Schubert, 1994). Development of such strike-slip fault zone perpendicular to main trend of the MPT was most probably a result of oblique orientation of regional inversion-related compressional stresses to main, NW-SE trending tectonic grain of this basin (see below).

\section{Discussion}

Presented seismic examples document basement brittle deformations formed during development and inversion of the MPT. Within the axial part of the MPT significant mechanical decoupling between Palaeozoic (pre-Zechstein) basement and Mesozoic sedimentary infill caused by the presence of thick Zechstein evaporites resulted in various modes of subsidence for these two structural complexes. Such decoupling also played significant role during basin inversion and prevented continuation of basement faults into the Mesozoic infill section. A model for Mesozoic development of the Pomeranian segment of the MPT was constructed (Fig. 11). It is based on interpreted seismic data flattened on top of Zechstein (Fig. 11a), top of Triassic (Fig. 11b) and top of Jurassic (Fig. 11c). Due to intracratonic and epicontinental character of the MPT and lack of significant sediment progradation such flattening could be safely accepted as first but reliable approximation of MPT's reconstructed upper crustal configuration for particular time-slices. Due to strong erosion within the axial part of the inverted MPT it is difficult to estimate pre-inversion geometry of the MPT. Estimates of erosion based on compaction analysis suggest that within the Pomeranian segment of the MPT inversion-related erosion was in order of up to $2 \mathrm{~km}$ (Dadlez, Jóźwiak and Młynarski, 1997). Other authors however criticised these estimates (Świdrowska and Hakenberg, 1999). Therefore, both restored basin geometry flattened on top of Jurassic (Fig. 11c) as well as estimated amount of eroded deposits within the 
$\mathrm{D}$

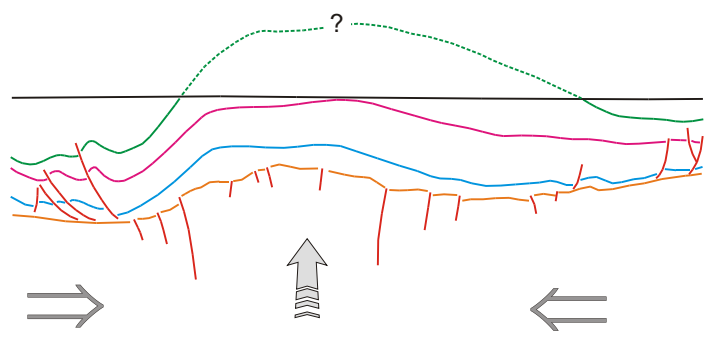

C

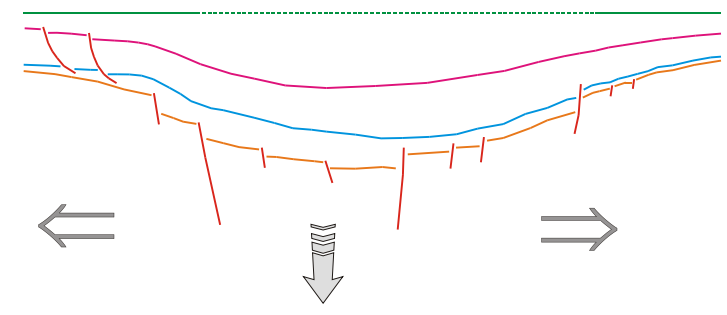

B

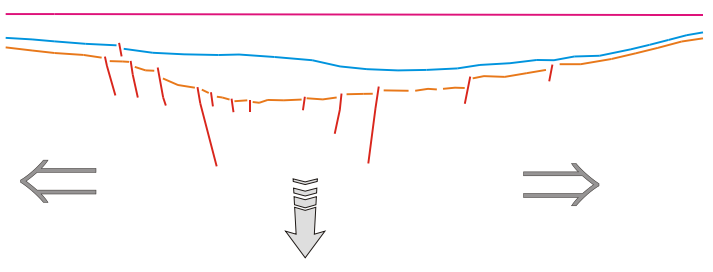

A

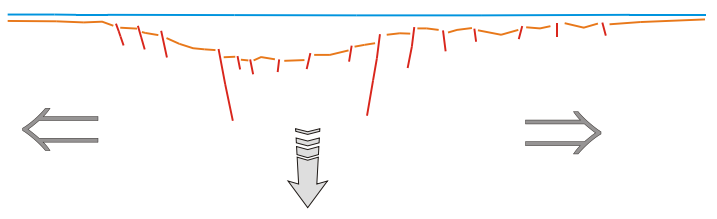

Fig. 11. Qualitative model for Late Permian-Mesozoic evolution of the Pomeranian segment of the Mid-Polish Trough based on interpreted seismic profile from Fig. 4 (not to scale). (a) - Late Permian (deposition of Zechstein evaporites), (b) - Triassic, (c) - Jurassic, (d) - recent. Note that due to strong uplift all Cretaceous and Jurassic deposits from the axial part of uplifted Mid-Polish Swell have been eroded, hence estimations of their thickness are difficult, and restoration for Jurassic times (c) should be regarded as very approximate. Basement faults responsible for basin development and inversion should be regarded as presumed.

MPT's axial part (Fig. 11d) should be regarded only as a very general approximations of Jurassic and present-day upper crustal geometries. Despite uncertainties related to exact amount of uplifted and eroded Cretaceous and Jurassic deposits within axial part of the MPT, this model does presents idea of basin development above basin-scale detachment surface within the thick Zechstein evaporites. During Late Permian (approx. deposition of Zechstein evaporites) to Jurassic and earliest Late Cretaceous times (Fig. 11a,b and c) basement extension was responsible for tectonic subsidence. Due to decoupling caused by thick evaporites normal faulting did not affect post-Zechstein deposits and only secondary smallscale deformations developed within the Mesozoic infill. It is also characterised by rather smooth thickness changes and divergent seismic pattern. During Late Cretaceous inversion major basement normal faults were reactivated and could have acted as reverse faults (Fig. 11d). For the MPT Pomeranian segment indirect estimates suggest that uplift of its axial part related to inversion activity spanned Turonian to Campanian times. Within the Radom-Kraśnik Elevation inversion may have started in Coniacian, was active in Santonian and Campanian, and reached its peak in Maastrichtian times. A model was constructed that presents major stages of Mesozoic evolution of this part of the MPT (Fig. 12). During extensional stage basement normal faults directly governed distribution of syn-extensional (Triassic - Jurassic - Lower Cretaceous; Fig. 12a and b) deposits. Sediment supply was generally towards the SW, i.e. towards axial part of the MPT (cf. Kutek and Głazek, 1972). Decoupling between Palaeozoic basement and Mesozoic infill described from other parts of the MPT was not present in this part of the basin due to lack of thick viscous salt deposits. During MPT inversion area of the present-day Holy Cross Mts. and their surroundings has been uplifted and eroded, and particular inverted basement blocks provided syn-inversion deposits to flanking remnant basin (Fig. 12c).

Inversion along NE boundary of the MPT was associated with strike-slip movements. First stage of inversion related to uplift of axial part of the MPT can be approximately dated as post-Turonian and pre-Maastrichtian, second stage related to strike-slip movements can be dated as middle Maastrichtian. Maastrichtian is also the age of transversal strike-slip activity along Grójec fault. This is in general agreement with earlier conclusions on timing of regional inversion of the PolishDanish basin (see e.g. Dadlez et al., 1995 and Ziegler, 1989, 1990 for extensive summary and numerous references). They are however partly different from recent, more detailed estimates based on regional thickness and facies analysis for Upper Cretaceous deposits (Świdrowska and Hakenberg, 1999). These authors suggest that during Turonian no inversion activity took place within the entire MPT; for the Pomeranian segment of the MPT Turonian to Santonian basin shallowing has resulted from uplift of southern Baltic sea rather than from basin inversion, and real inversion started in this area only in Campanian. Such partial discrepancy between age estimates based on different datasets could be explained by methodological differences. Regional analysis of paleogeographic maps, especially for strongly eroded areas, is by definition biased by distribution of wells used for their construction. On the other hand interpretation of modern seismic reflection data provides fairly precise information on localised thickness changes and other syn-tectonic features along continuous profiles that could date local inversion activity even for relatively small areas. For given well distribution and stratigraphic resolution it is often not possible to infer facies or thickness variations observed on seismic profiles. Therefore time estimates for inversion for particular parts of the MPT presented in this paper should be regarded as more re- 
liable. Future work should concentrate on re-evaluation of stratigraphic information from selected wells located in close vicinity of key seismic profiles in order to obtain more precise time constrains for dating various stages of MPT evolution, particularly its inversion.

Presented examples of upper crustal brittle deformations developed during basin inversion strongly suggest that the MPT has been inverted due to transmission of compressional stresses and reactivation of inherited normal faults. Two regional processes could have been responsible for foreland deformations and inversion of Peri-Tethyan epicontinental sedimentary basins: spreading within the Atlantic domain and Alpine-Carpathian collisional (Dadlez, 1980a; Ziegler, 1990; Golonka et al., 2000).

During Late Cretaceous development of the Atlantic rift system Rockall Trough, Labrador Sea and Bay of Biscay rift axes were active (Ziegler, 1990). In particular, as already pointed out by Golonka et al., (2000), Bay of Biscay spreading was parallel to the arrangement of NW-SE trending major inverted structures of Western and Central Europe. Therefore ridge push from Bay of Biscay spreading was proposed as a possibly important source of compressional stresses that could have been transferred far into the foreland plate and cause inversion. This would however require stress transfer along considerable distances for reactivation of inherited MPT basement fault zones, and at the same time lack of major inversion structures in the foreland of the Western Alps i.e. in the area located much closer to the Bay of Biscay spreading axis (cf. Ziegler, 1990). Additionally, presence of important strike-slip fault zones active during the MPT inversion suggests that regional stresses were at least partly oriented obliquely to NW-SE trending MPT, hence their origin might not be related to the Bay of Biscay spreading centre, which was parallel to the MPT.

Cretaceous collision within the Alps resulted from NESW convergence between European and African plates and affected mainly Western and Eastern Alps (Pfiffner, 1992). Late Turonian - Early Senonian collision at the PenninicHelvetic boundary most probably resulted in formation of A-subduction and stacking of Austro-Alpine and Penninic nappe system (Ziegler, 1989). Compressional stresses generated by these collisional events within the Alpine domain and transferred into foreland plate could have inducted inversion of sedimentary basins such as MPT. This is suggested by general age correlation between collision and foreland inversion. Within the Carpathian domain numerous tectonic events could be shown that might also be responsible for compressional stresses transferred into the foreland plate. During Late Cretaceous both Inner Carpathians and Pieniny Klippen Belt were subjected to several shortening and subduction events partly accompanied by strikeslip movements (Birkenmajer, 1986; Nemčok and Nemčok, 1994; Winkler and Śla̧czka, 1994; Plašienka et al., 1997; Golonka, Oszczypko and Ślączka, 2000). Early stages of compression within the Pieniny Klippen Belt were dated as Aptian-Turonian or Senonian, and main stages of subduction and compression were dated as Campanian, Maas-
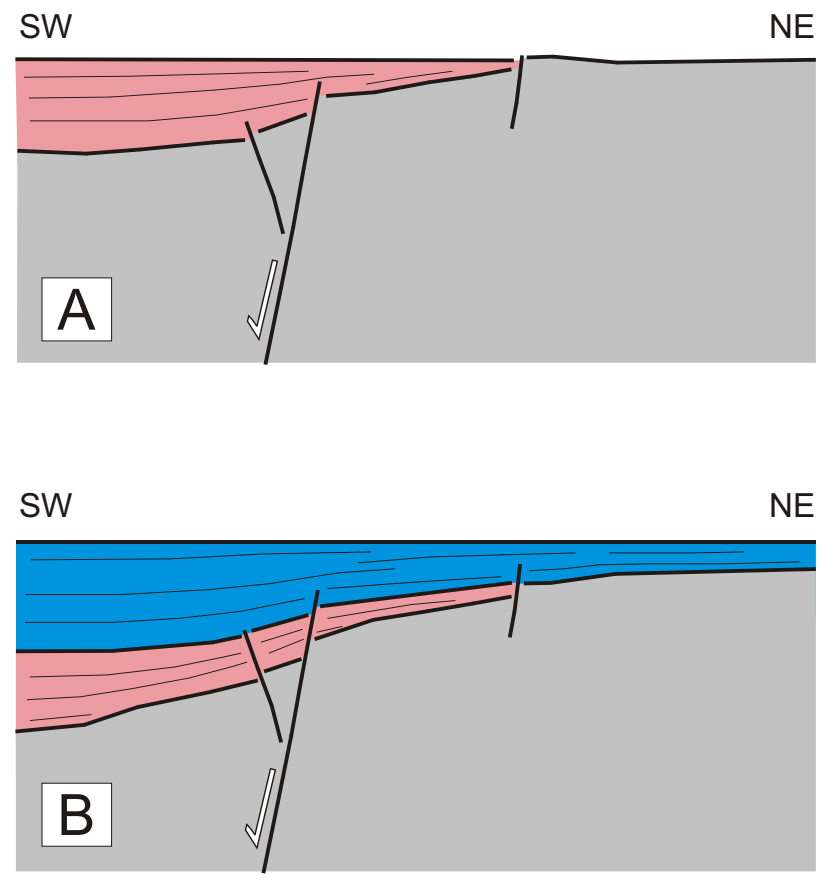

SW

NE

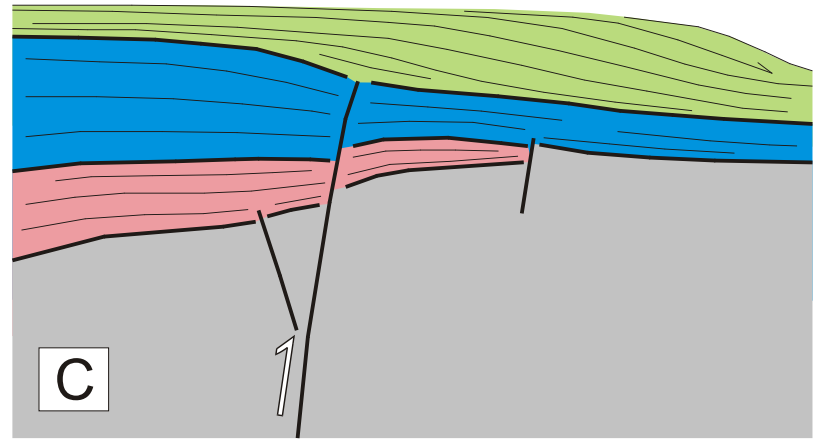

Fig. 12. Qualitative model of Mesozoic evolution of the Radom Kraśnik Elevation based on interpreted seismic scale from Fig. 7 (not to scale). Extensional stage: (a) (Triassic) and (b) (Jurassic Early Cretaceous), inversion stage: (c) (Late Cretaceous).

trichtian and Palaeocene (Birkenmajer, 1986). Within the Inner Carpathians Late Cretaceous collision and compression was related to suturing of the Penninic-Vahic oceanic realms (Plašienka et al., 1997). Additonally, analysis of subsidence curves suggest influence of compressional events within the Inner Carpathians on Pieniny Klippen Belt evolution during Late Cretaceous, i.e. suggest mechanical link between these two domains (Poprawa and Krobicki, 1996).

During all Alpine-Carpathian collisional events mentioned above compressional stresses could have been transferred into the foreland plate and led to inversion of the MPT. This would indicate that Alpine-Carpathian orogenic system was mechanically coupled with its foreland. It must 
be noted however that during Late Cretaceous collisional events, between Inner Carpathian domain and European Platform large sedimentary basins of the Outer Carpathians existed. They were underlain by either oceanic or thinned continental crust and characterised, especially during AlbianCenomanian / Turonian, by uniform pelagic sedimentation in abyssal depths (Winkler and Ślączka, 1994; Golonka, Oszczypko and Ślączka, 2000). It remains therefore questionable to what extent compressional stresses generated by collision within the Inner Carpathian domain could have been transferred across vast sedimentary basins without major effect on their sedimentation and tectonic pattern, but would led at the same time to significant inversion of much more distant structures of the MPT. Other authors however suggest on the basis of subsidence analysis of the Outer Carpathian basins that during Turonian-Maastrichtian and Paleocene they were subjected to minor uplift and characterised by slight increase of deposition rate (Poprawa and Malata, 2000). If true, this scenario would justify hypothesis of relatively strong mechanical coupling between the Carpathian orogenic belt and its foreland plate that was suggested in this paper on the basis of completed interpretation of seismic data from the MPT.

\section{Conclusions}

Interpretation of seismic data from various parts of the MidPolish Trough provided new information on timing and inversion style of this sedimentary basin:

1. In axial part of the MPT, characterised by thick Zechstein deposits, mechanical decoupling between preZechstein basement and post-Zechstein sedimentary infill strongly influenced MPT evolution, including its inversion.

2. In areas without significant influence of Zechstein deposits on tectonic processes, classical upper crustal inversion structures have been interpreted like reverse faults and uplifted basement blocks.

3. Thickness reductions and local angular unconformities pointing to syn-tectonic sedimentation often accompany identified inversion structures.

4. For the NW (Pomeranian) segment indirect observations suggest that inversion activity spanned Turonian to Campanian times, whereas in SE segment (RadomKraśnik Elevation) inversion could have started in Coniacian, was active in Santonian and Campanian, and reached its peak in Maastrichtian times.

5. Inversion along the NE boundary of the MPT (KoszalinChojnice tectonic zone) was associated with strike-slip movements. In this area the first stage of the inversion can be dated as possibly post-Turonian and pre-Maastrichtian, the second stage as middle Maastrichtian.
6. Inversion - related of transverse strike-slip activity along Grójec fault took place in Maastrichtian.

7. All the obtained dates of MPT inversion generally conform to the main compressive events within the AlpineCarpathian orogenic belt, which suggests some sort of mechanical coupling between this orogenic belt and its foreland.

Acknowledgement. Research on MPT evolution was partly funded by KBN grant No 9T12B02415 (to P. Krzywiec). Acquisition and interpretation of high-resolution seismic data from the southern Baltic Sea was completed within NFOŚiGW grant No 2.03.0010.00.0 (to R. Kramarska). Petrobaltic, Polish Oil \& Gas Company and Apache-Poland oil companies are thanked for making seismic data available for this study. P. Zientara is thanked for maintaining seismic database, J. Szewczyk and S. Wronicz for preparation of selected well data, and W. Jóźwiak for well database maintenance and help with figures drafting. Careful and constructive reviews by R. Dadlez (Warszawa) and R. Stephenson (Amsterdam) are acknowledged. Their remarks and comments, although not fully accepted and included in this text, greatly helped to finally shape this contribution. Sincere thanks are also due to all participants of EUROPROBE research programme (especially PANCARDI and TESZ groups) for numerous very stimulating discussions.

\section{References}

Antonowicz, L., Iwanowska, E., and Rendak, A.: Tensional tectonics in the Pomeranian section of the T-T Zone and the implications for hydrocarbon exploration, Geological Quarterly, 38, 2: 289-306, 1994.

Biddle, K. and Christie-Blick, N.: Glossary - strike-slip deformation, basin formation, and sedimentation, in: Biddle K. and Christie-Blick N. (Eds.): Strike-slip deformation, basin formation, and sedimentation, Society of Economic Paleontologists and Mineralogists Special Publication, 37, 375-386, 1985.

Birkenmajer, K.: Stages of structural evolution of the Pieniny Klippen Belt, Carpathians, Studia Geologica Polonica, 88: 7-32, 1986.

Buchanan J. G. and Buchanan, P. G.: Basin Inversion, Geological Society Special Publication, 88, 596pp, 1995.

Burbank, D. W. and Verges, J.: Reconstruction of topography and related depositional systems during active thrusting, Journal of Geophysical Research, 99, B10, 20 281-20 297, 1994.

Cartwright, J. A.: Transverse structural zones in continental rifts an example form the Danish Sector of the North Sea, in: Brooks, J. and Glennie, K. (Eds.): Petroleum Geology of North West Europe, Graham \& Trotman, London, 441-452, 1987.

Cartwright, J. A.: The kinematics of inversion in the Danish Central Graben, in: Cooper, M. A. and Williams, G. D. (Eds.): Inversion Tectonics, Geological Society Special Publication, 44, 153-175, 1989.

Christie-Blick, N. and Biddle, K.: Deformation and basin formation along strike-slip faults, in: Biddle, K. and Christie-Blick, N. (Eds.): Strike-slip deformation, basin formation, and sedimentation, Society of Economic Paleontologists and Mineralogists Special Publication, 37, 1-34, 1985. 
Cooper, M. A. and Williams, G. D. (Eds.): Inversion Tectonics, Geological Society Special Publication, 44, 375pp, 1989.

Coward, M. P.: Inversion tectonics, in: Hancock, P. L. (Ed.): Continental Deformation, Pergamon Press, 289-304, 1994.

Dadlez, R.: Tectonics of the Pomeranian Swell (NW Poland), Kwartalnik Geologiczny, 24, 4, 741-767 (in Polish with English summary), 1980a.

Dadlez, R.: Fault pattern in the Polish Lowlands and its bearing on the Permian-Mesozoic evolution of the area, Przegląd Geologiczny, 5, 278-287, 1980b.

Dadlez, R.: Pre-Caiozoic tectoics of the S Baltic Sea, Geological Quarterly, 37, 431-450, 1993.

Dadlez, R.: Strike-slip movements in the Polish Lowlands, Geological Quarterly, 38, 2, 307-318, 1994.

Dadlez, R.: Epicontinental basins in Poland: Devonian to Cretaceous - relationship between the crystalline basement and sedimentary infill, Geological Quarterly, 41, 4, 419-432, 1997.

Dadlez, R. and Dembowska, J.: Przebieg i wyniki badań podłoża mezozoicznego w atyklinorium pomorskim w latach 1953-1958, Przegląd Geologiczny, 7, 248-254, 1959.

Dadlez, R., Iwanow, A., Leszczyński, K., and Marek, S.: Tectonic map of the Zechstein-Mesozoic complex in the Polish Lowlands, Państwowy Instytut Geologiczny, Warszawa, 1998.

Dadlez, R. and Marek, S.: Structural style of the ZechsteinMesozoic complex in some areas of the Polish Lowland, Kwartalnik Geologiczny, 3, 543-565 (in Polish with English summary), 1969.

Dadlez, R., Marek, S.: General Outline of the Tectonics of the Zechstein-Mesozoic Complex in Central and Northwestern Poland, Biuletyn Instytutu Geologicznego, 274, 11-140, 1974.

Dadlez, R., Marek, S., and Pokorski, J. (Eds.): Palaeogeographic atlas of epicontinental Permian and Mesozoic in Poland (1: 2500 000), Wydawnictwo Kartograficzne Polskiej Agencji Ekologicznej, Warszawa, 1998.

Dadlez, R. and Młynarski, S.: Deep geological structure of the Baltic Sea substratum east of the Odra river mouth, Kwartalnik Geologiczy, 11, 488-501 (in Polish with English summary), 1967.

Dadlez, R., Narkiewicz, M., Stephenson, R. A., Visser, M. T. M., and Van Wees, J.-D.: Tectonic evolution of the Mid-Polish Trough: modelling implications and significance for central European geology, Tectonophysics, 252, 179-195, 1995.

Dadlez, R., Jóźwiak, W., and Młynarski, S.: Subsidence and inversion in the western part of Polish Basin-data from seismic velocities, Geological Quarterly, 41(2), 197-208, 1997.

Deeks, N. R. and Thomas, S. A.: Basin inversion in strike-slip regime: the Tornquist Zone, Southern Baltic Sea, in: Buchanan, J. G. and Buchanan, P. G. (Eds.): Basin Inversion, Geological Society Special Publication, 88, 319-338, 1995.

Dembowska, J. (Ed.): Człuchów IG-1, Profile głębokich otworów wiertniczych Instytutu Geologicznego, 42, 137pp (in Polish), 1977.

Dronkers, A. J. and Mrozek, F. J.: Inverted basins of The Netherland, First Break, 9, 9, 409-425, 1991.

Dunne, W. M. and Ferill, D. A.: Blind thrust systems, Geology, 16, 33-36, 1988.

Erlstrom, M., Thomas, S. A., Deeks, N., and Sivhed, U.: Structure and tectonic evolution of the Tornquist Zone and adjacent sedimentary basins in Scania and southern Baltic Sea area, Tectonophysics, 271, 191-216, 1997.

Golonka, J., Oszczypko, N., and Ślączka, A.: Late CarboniferousNeogene geodynamic evolution and palaeogeography of the
circum-Carpathian region and adjacent areas, Annales Societatis Geologorum Poloniae, 70, 107-136, 2000.

Hakenberg, M. and Świdrowska, J.: Propagation of the southeastern segment of the Polish Trough connected with bounding fault zones (from Permian to the Late Jurassic), C. R. Acad. Sci., Paris, 324, II, 793-803, 1997.

Hakenberg, M. and Świdrowska, J.: Rozwój południowego segmentu bruzdy polskiej i jego związek ze strefami uskoków ograniczających (od permu do późnej jury), Przeglạd Geologiczny, 46, 6, 503-508 (in Polish), 1998a.

Hakenberg, M. and Świdrowska, J.: Evolution of the Holy Cross segment of the Mid-Polish Trough during the Cretaceous, Geological Quarterly, 42, 3, 239-262, 1998 b.

Harding, T. P.: Seismic characteristics and identification of negative flower structures, positive flower structures, and positive structural inversion, American Association of Petroleum Geologists Bulletin, 69, 4, 582-600, 1985.

Hardy, S., Poblet, J., McClay, K. R., and Waltham, D.: Mathematical modelling of growth strata associated with fault-related structures, in: Buchanan, P. G. and Nieuwland, D. A. (Eds.): Modern developments in structural interpretation, validation and modelling, Geological Society Special Publication, 99, 262-282, 1996.

Hayward, R. H. and Graham, A. B.: Some geometrical characteristic of inversion, in: Cooper, M. A. and Williams, G. D. (Eds.): Inversion Tectonics, Geological Society Special Publication, 44, 17-39, 1989.

Herbich, E.: Analiza tektoniczna uskoków w okolicy Lipna i Sierpca wyznaczonych metodą sejsmiczna̧, Przegląd Geologiczny, 32, 3, 142-14 (in Polish), 1984.

Izotova, T. S. and Popadyuk, I. V.: Oil and gas accumulations in the Late Jurrasic reefal complex of the West Ukrainian Carpathian foredeep, in: Ziegler, P. A. and Horvath, F. (Eds.): Peri-Tethys Memoir 2: structure and prospects of the alpine basins and forelands, Mem. Mus. natn. Hist. nat., 170, 375-390, 1996.

Jaroszewski, W.: Drobnostrukturalne kryteria tektoniki obszarów nieorogenicznych na przykładzie północno-wschodniego obrzeżenia mezozoicznego Gór Świętokrzyskich, Studia Geologica Polonica, 38, 215pp (in Polish), 1972.

Jaskowiak-Schoeneich, M.: Kreda górna, in: Dadlez, R. (Ed.): Perm i mezozoik Niecki Pomorskiej, Prace Instytutu Geologicznego, 79, 94-105, 1976.

Karnkowski, P. H.: Origin and evolution of the Polish Rotligend Basin, Polish Geological Institute Special Papers, 3, 93pp, 1999.

Koyi, H., Jenyon, M. K., and Petersen, K.: The effect of basement faulting on diapirism, Journal of Petroleum Geology, 16(3), 285312, 1993.

Koyi, H. and Petersen, K.: Influence of basement faults on the development of salt structures in the Danish Basin, Marine and Petroleum Geology, 10(20), 81-94, 1993.

Koyi, H., Talbot, C. J., and Torundbakken, B. O.: Analogue modelling of salt diapirs and seismic interpretation in the Nordkapp Basin, Norway, Petroleum Geoscience, 1, 185-192, 1995.

Kramarska, R., Krzywiec, P., and Dadlez, R.: Geological map of the Baltic Sea bottom without Quaternary deposits, Państwowy Instytut Geologiczny, Gdańsk-Warszawa, 1999.

Krzywiec, P.: Large-scale tectono-sedimentary Middle Miocene history of the central and eastern Polish Carpathian Foredeep Basin-results of seismic data interpretation, Przegląd Geologiczny, 45, 10/2, 1039-1053, 1997.

Krzywiec, P.: Miocene tectonic evolution of the E Polish Carpathian Foredeep basin (Przemyśl-Lubaczów area) in light of 
seismic data interpretation, Prace Państwowego Instytutu Geologicznego, CLXVIII, 249-276 (in Polish with extended English summary), 1999.

Krzywiec, P.: On mechanism of the Mid-Polish Trough inversion, Polish Geological Institute Bulletin, 393, 135-166 (in Polish with extended English summary), 2000a.

Krzywiec, P.: Mid-Polish Trough inversion-seismic examples and main mechanisms, EUROPROBE (TESZ)-PACE Meeting, Zakopane, 16.-23.09.2000, Abstract Volume, 50-52, 2000b.

Krzywiec, P.: Tectonostratigraphic model of Late Cretaceous inversion of the Radom-Kraśnik Elevation (SE Mid-Polish Trough) - results of seismic data interpretation, EUROPROBE (TESZ)PACE Meeting, Zakopane, 16.-23.09.2000, Abstract Volume, 52-53, 2000c.

Krzywiec, P., Szulc, J., Wysocka, A., Królikowski, C., and Petecki, Z.: Extension, inversion and salt tectonics, central Mid-Polish Trough - a model, EUROPROBE (TESZ)-PACE Meeting, Zakopane, 16.-23.09.2000, Abstract Volume, 54-55, 2000d.

Krzywiec, P.: Contrasting tectonic and sedimentary history of the central and eastern parts of the Polish Carpathian Foredeep Basin - results of seismic data interpretation, in: Cloetingh, S., Nemčok, M., Neubauer, F., Horvath, F., and Seifert, P. (Eds.): The Hydrocarbon potential of the Carpathian-Pannonian Region, Marine and Petroleum Geology, 18(1), 13-38, 2001.

Kutek, J.: Jurassic tectonic events in south-eastern cratonic Poland. Acta Geol. Pol., 44, 3-4, 167-221, 1994.

Kutek, J. and Głazek, J.: The Holy Cross Area, Central Poland, in the Alpine Cycle, Acta Geologica Polonica, 22, 4, 603-653, 1972.

Lamarche, J., Świdrowska, J., Bergerat, F., Hakenberg, M., Mansy, J.-L., Wieczorek, J., Stupnicka, E., and Dumont, T.: Development and deformation of a Mesozoic basin adjacent to the Teisseyre-Tornquist Zone: The Holy Cross Mountains (Poland), in: Crasquin-Soleau, S. and Barrier, E. (Eds.): Peri-Tethys Memoir 4: Epicratonic basins of Peri-Tethyan platforms, Mem. Mus. Natn. Hist. Nat., 179, 75-92, 1998.

Lihou, J. C. and Allen, P. A.: Importance of inherited rift margin structures in the early North Alpine Foreland Basin, Switzerland, Basin Research, 8, 425-442, 1996.

McClay, K. R.: Analogue models of inversion tectonics, in: Cooper, M. A. and Williams, G. D. (Eds.): Inversion Tectonics, Geological Society Special Publication, 44, 41-59, 1989.

McClay, K. R.: The geometrics and kinematics of inverted fault systems: a review of analogue model studies, in: Buchanan, J. G. and Buchanan, P. G. (Eds.): Basin Inversion, Geological Society Special Publication, 88, 97-118, 1995.

McClay, K. R. and Buchanan, P. G.: Thrust faults in inverted extensional basins, in: McClay, K. R. (Ed.): Thrust Tectonics, Chapman \& Hall, 93-104, 1992.

Michelsen, O.: 1997 - Mesozoic and Cenozoic stratigraphy and structural development of the Sorgenfrei-Tornquist Zone, Z. dt. geol. Ges., 148, 1, 33-50.

Mitra, S.: Duplex structures and imbricate thrust systems: geometry, structural position, and hydrocarbon potential, Association of Petroleum Geologists Bulletin, 70, 9, 1087-1112, 1986.

Mitra, S.: Fault-propagation folds: geometry, kinematic evolution, and hydrocarbon traps, Association of Petroleum Geologists Bulletin, 74, 6, 921-945, 1990.

Mitra, S.: 1993 - Geometry and kinematic evolution of inversion structures, American Association of Petroleum Geologists Bulletin, 77, 7, 1159-1191.

Mitra, S. amd Islam, Q. T.: Experimental (clay) models of inversion structures, Tectonophysics, 230, 211-222, 1994.

Niemczycka, T. (Ed.): Ciepielów IG-1, Profile głębokich otworów wiertniczych Instytutu Geologicznego, 20, 247pp, 1974.

Niemczycka, T. (Ed.): Ba̧kowa IG-1, Profile głębokich otworów wiertniczych Instytutu Geologicznego, 26, 182pp, 1975.

Nemčok, M. and Nemčok, J.: Late Cretaceous deformation of the Pieniny Klippen Belt, West Carpathians, Tectonophysics, 239, 81-109, 1994.

Oszczypko, N., Zając, R., Garlicka, I., Mencik, E., Dvorak, J., and Matejovska, O.: Geological map of the substratum of the Tertiary of the western outer Carpathians and their foreland (1:500 000), Państwowy Instytut Geologiczny, Warszawa, 1989.

Pfiffner, A.: Alpine orogeny, in: Blundell, D., Freeman, R., and Mueller, S. (Eds.): A Continent Revealed: the European Geotraverse, Cambridge University Press,, London, 180-190, 1992.

Pietsch, K. and Krzywiec, P.: Application of seismic methods for hydrocarbon exploration within the Devonian and Carboniferous series of the Western Pomerania (Białogard-Jamno area), Oil and Gas News from Poland, 6, 175-186.

Plašienka, D., Grecula, P., Putiš, M., Kovač, M., and Hovorka, D.: Evolution and structure of the Western Carpathians: an overwiev, in: Grecula, P., Hovorka, D., and Putiš, M. (Eds.): Geological evolution of the Western Carpathians, Mineralia Slovaca, Bratislava, 1-24, 1997.

Poprawa, P. and Malata, T.: Analysis of subsidence / uplift and source area activity for the Late Jurassic to Miocene Polish Outer Carpathian sedimentary basins - regional implications, Vijest Hrvatskoga geoloskog drustva (EUROPROBE-PANCARDI Volume), 37(3), 103-104, 2000.

Poprawa, P. and Krobicki, M.: Subsidence analysis of reconstructed profiles of the Pieniny Klippen Belt, Mitteilungen der Gesellschaft der Geologie and Bergbaustudenten in Österreich (EUROPROBE-PANCARDI Volume), 41, 128-129, 1996.

Pożaryski, W.: The Southwestern Margin of Fenno-Sarmatia, Kwartalnik Geologiczny, 1(3-4), 383-424, (in Polish with English summary), 1957.

Pożaryski, W.: Jura i kreda między Radomiem, Zawichostem i Kraśnikiem, Biul, Państwowego Instytutu Geologicznego, 46, 5141, 1948.

Pożaryski, W.: Geology of Poland, IV (Tectonics), Wydawnictwa Geologiczne, Warszawa, 1977.

Pożaryski, W.: Tektonika powaryscyjska obszaru świętokrzyskolubelskiego na tle struktury podłoża, Przegląd Geologiczny, 45, 12, 1265-1270 (in Polish), 1997.

Pożaryski, W. and Brochwicz-Lewiński, W.: On the Polish Trough, Geol. en Mijnbow., 57, 4, 545-557, 1978.

Pożaryski, W. and Brochwicz-Lewiński, W.: On the Mid-Polish Aulacogen, Kwartalnik Geologiczny, 23, 2, 271-290 (in Polish with English summary), 1979.

Pożaryski, W., Brochwicz-Lewiński, W., and JaskowiakSchoeneich, M.: Geologiczna mapa Baltyku, Przegląd Geologiczny, 1, 1-5, 1978.

Pożaryski, W. and Witkowski, A.: Geology of southern Baltic area (without Cenozoic), Przegląd Geologiczny, 5-4, 221-227 (in Polish with English summary), 1990.

Pożaryski, W. and Żytko, K.: On the Mid-Polish Aulacogen and the Carpathian Geosyncline, Bull, Acad. Pol. Sc. Ser. Sc. Terre, 28, 4, 303-316, 1981.

Roure, F. and Colletta, B.: Cenozoic inversion structures in the foreland of the Pyrenees and Alps, in: Ziegler, P. A. and Horvath, F. (Eds.): Peri-Tethys Memoir 2: Structure and prospects of Alpine basins and forelands, Mem. Mus. natn. Hist. nat., 170, 173-209, 
1996.

Rowan, M. G., Jackson, M. P. A., and Trudgill, B. D.: Salt-related fault families and fault welds in the northern Gulf of Mexico, Association of Petroleum Geologists Bulletin, 83, 9, 1454-1484, 1999.

Jaskowiak-Schoeneich, M.: The geological structure of the Szczecin Trough ad Gorzów Block, Prace Instytutu Geologicznego, XCVI, 178pp, 1979.

Schlüter, H.-U., Best, G., Jürgens, U., and Binot, F.: Interpretation reflexionseismischer Profile zwischen baltischer Kontinentplatte und kaledonischem Becken in der südlichen Ostsee - erste Ergebnisse, Z. Dt. Geol. Ges., 148, 1, 1-32, 1997.

Schröder, B.: Inversion tectonics along the western margin of the Bohemian Massif, Tectonophysics, 137, 93-100, 1987.

Sokołowski, J.: The role of halokinesis in the development of Mesozoic and Cainozoic deposits of the Mogilno structure and of the Mogilno-Lódź Synclinorium, Prace Instytutu Geologicznego, L., 112pp (in Polish with English summary), 1966.

Sokołowski, J.: Rola tektoniki salinarnej cechsztynu w modelowaiu pokrywy mezo-kenozoiczej, in: Osika, R. (Ed.): Uroczysta Sesja Naukowa z okazji 50-lecia istnienia Instytutu Geologicznego, Warszawa, Wydawnictwa Geologiczne, 99-118 (in Polish), 1972.

Stackenbrandt, W. and Franzke, H. J.: Alpidic reactivation of the Variscan consolidated lithosphere - the activity of some fracture zones in central Europe, Z. geol. Wiss., 17(7), 699-712, 1989.

Stephenson, R. A. and Narkiewicz, M.: Tectonic subsidence modelling of the Polish Basin in the light of new data on crustal structure and magnitude of inversion, Romanian Journal of Tectonics and Regional Geology, 77, 1-51, 1999.

Strzetelski, W., Górecki, W., Krzywiec, P., Pietsch, K., and Reicher, B.: Tectonic history and hydrocarbon habitat of Western Pomerania, N Poland - results of integrated geological and geophysical study, Abstract book, 57th EAPG/EAEG Conference, Glasgow, UK., 1995.

Stupnicka, E.: Tektonika utworów mezozoicznych południowego obrzeżenia Gór Świętokrzyskich, Rocznik Polskiego Towarzystwa Geologicznego, 40, 3-4, 393-410 (in Polish), 1971.

Stupnicka, E.: Tectonics of the SW margin of the Holy Cross Mts. Biuletyn Geologiczny Uniwersytetu Warszawskiego, 14, 21-114 (in Polish with English summary), 1972.

Szyperko-Śliwczyńska, A.: Dokumentacja wynikowa otworów badawczych Człuchów IG-2 i Człuchów IG-2bis (opracowanie archiwalne), Centralne Archiwum Geologiczne, Warszawa (in Polish), 1977.

Świdrowska, J. and Hakenberg, M.: Subsidence and the problem of incipient inversion in the Mid- Polish Trough based on thickness maps and Cretaceous lithofacies analysis, Przegląd Geologiczny, 47(1), 61-68 (in Polish with English summary), 1999.

Świdrowska, J. and Hakenberg, M.: Palaeotectonic conditions of Cretaceous basin development in the southeastern segment of the Mid-Polish Trough, in: Crasquin-Soleau, S. and Barrier, E.
(Eds.): Peri- Tethys Memoir 5: New data on Peri-Tethyan sedimentary basins, Mem. Mus. Natn. Hist. Nat., 182, 239-256, 2000.

Trudgill, B., Rowan, M. G., Fiduk, J. C., Weimer, P., Gale, P. E., Korn, B. E., Phair, R. L., Gafford, W. T., Robertes, G. R., and Dobbs, S. W.: The Perdido fold belt, northwestern Gulf of Mexico: part 1; structural geometry, evolution, and regional implications, Association of Petroleum Geologists Bulletin, 83, 88-113, 1999.

Van Wees, J.-D., Stephenson, R. A., Ziegler, P. A., Bayer, U., McCann, T., Dadlez, R., Gaupp, R., Narkiewicz, M., Bitzer, F., and Scheck, M.: On the origin of the Southern Permian Basin, Central Europe, Marine and Petroleum Geology, 17, 43-59, 2000.

Vejbaek, O. W., Stouge, S., and Poulsen, K. D.: Paleozoic tectonic and sedimentary evolution and hydrocarbon prospectivity in the Bornholm area, Geological Survey of Denmark, DGU Serie A, 34, $23 \mathrm{pp}, 1994$.

Wagner, R.: Zechstein, in: Dadlez, R., Marek, S., and Pokorski, J. (Eds.): Palaeogeographic atlas of epicontinental Permian and Mesozoic in Poland (1:2 500 000), Wydawnictwo Kartografíczne Polskiej Agencji Ekologicznej, Warszawa, 1998.

Williams, G. D., Powell, C. M., and Cooper, M. A.: Geometry and kinematics of inversion, in: Cooper, M. A. and Williams, G. D. (Eds.): Inversion Tectonics, Geological Society Special Publication, 44, 3-15, 1989.

Winkler, W. and Ślączka, A.: A Late Cretaceous to Palaeogene geodynamic model for the Western Carpathians in Poland, Geologica Carpathica, 45(2), 71-82, 1994.

Withjack, M. O., Olson, J., and Petersen, E.: Experimental models of extensional forced folds, American Association of Petroleum Geologists Bulletin, 74(7), 1038-1054, 1990.

Withjack, M. O. and Callaway, S.: Active normal faulting beneath a salt layer: an experimental study of deformation patterns in the cover sequences, American Association of Petroleum Geologists Bulletin, 84(5), 627-651, 2000.

Woodcock, N. H. and Schubert, C.: Continental strike-slip tectonics, in: Hancock, P. L. (Ed.): Continental deformation, Pergamon Press, London, 251-263, 1994.

Ziegler, P. A.: Geodynamic model for Alpine intra-plate compressional deformation in Western and Central Europe, in: Cooper, M. A. and Williams, G. D. (Eds.): Inversion Tectonics, Geological Society Special Publication, 44, 63-85, 1989.

Ziegler, P. A.: Geological atlas of western and central Europe, Shell Internationale Petroleum Maatschappij B. V., 239pp, 1990.

Znosko, J.: Teisseyre-Tornquist tectonic zone: some interpretative implications of recent geological and geophysical investigations, Acta Geologica Polonica, 29, 4, 365-382, 1979.

Żelichowski, A. M.: Tectonics of the Marginal Trough and its substrate in the zone of the Grójec fault (Warsaw-Dęblin area), Biuletyn Instytutu Geologicznego, 344, 199-224 (in Polish with English summary), 1983. 